\author{
섬유소분해효소 발효액의 첨가가 In vitro 발효 및 거세한우의 성장에 \\ 미치는 영향 \\ 국 길*·정완태** • 박홍석*** • 장기영* • 이지웅*·문승주*·김광현* \\ 전남대학교 동물자원학부*, 농촌진흥청 국립축산과학원**, 한국생명공학연구원***
}

\title{
The Effects of Aqueous Fibrolytic Enzyme Products Supplementation on In vitro Fermentation and Growth Performance of Hanwoo Steers
}

\author{
Kil Kook*, Wan Tae Chung**, Hong Seok Park***, Ki Yeoung Jang*, Ji Wung Lee*, Seung Ju Moon* \\ and Kwang Hyun Kim* \\ Division of Animal Science, Chonnam National University*, National Institute of Animal Science, RDA**,
} Korea Research Institute of Bioscience \& Biotechnology***

\begin{abstract}
The objective of this study was to investigate the effects of an enriched diet supplemented with aqueous fibrolytic enzyme products (FEP) on In vitro fermentation and growth performance of Hanwoo Steers. Total mixed ration combined with fibrolytic enzyme products showed a slight increase in the $\mathrm{pH}$ level on In vitro fermentation. Acetate ratio in volatile fatty acids, and the concentration of total volatile fatty acids were significantly greater at $12 \mathrm{hr}$ and $24 \mathrm{hr}$ after cultivation $(\mathrm{p}<0.05)$. Dry matter digestibility was significantly increased in groups supplied with aqueous fibrolytic enzyme products at $24 \mathrm{hr}$ after cultivation $(\mathrm{p}<0.05)$. In a rearing trial, the average daily gain and feed efficiency improved in the treatment groups supplied with aqueous fibrolytic enzyme products. Nutrient digestibility such as DM, crude fiber, NDF, and ADF digestibility were also significantly increased with the addition of aqueous fibrolytic enzyme products $(\mathrm{p}<0.05)$.

Therefore, the aqueous fibrolytic enzyme products supplementation on In vitro fermentation is effective in improving the condition of rumainal fermantation. Also two kinds of aqueous fibrolytic enzyme products were found to be effective in improving the average daily gain and feed efficiency in Hanwoo Steers.
\end{abstract}

(Key words : Fibrolytic enzyme, In vitro fermantation, Growth performance, Hanwoo)

\section{I. 서 론}

반추동물에 있어 섬유소분해효소 첨가는 섬유소의 분해를 증가시키고 가축의 생산성을 향상시키는 효과 가 있으며 (Beauchemin 등 2003), Yang 등 (1999)은 섬 유소분해효소는 반추위 미생물태단백질합성과 단백질 분해율을 향상시킨다고 보고하였다. Rode 등 (1999)은 섬유소분해효소는 착유우 사료의 건물과 섬유소 분해 를 증진시켰다고 하였으며, Feng 등 (1996)은 섬유소분 해효소는 in vitro 시험과 in situ 시험에서 건물소화율 을 증진시켰다고 보고하였다.

반추동물에서 섬유소분해효소는 동물의 생산성과 연계하여 특정효소 즉, 사료내 섬유소의 분해활성을 목적으로 여러 가지 미생물제가 이용되고 있다 (Beauchemin 등, 2001). 섬유소분해효소는 반추동물용 사료에 $0.01 \sim 1 \%$ 의 적은 적용비율에도 불구하고 가축
의 생산성에 긍정적인 효과를 나타낸다고 보고하고 있지만 (McAllister 등, 1999), 반추위내 이들의 작용기 전에 대한 충분한 자료가 부족하고 그 효과의 유효수 준, 사료의 조성, 사료급여체계, 동물의 성장단계 및 소화기관내 작용부위에 따라 기전이 다양하여 일관된 결과를 나타나지 않으며, 미생물효소제에 대한 반추동 물의 반응 또한 다양하게 나타나고 있다(Yang 등, 1999; Phipps 등, 2000; Sutton 등, 2003).

따라서 본 연구는 목재부후균 유래 $\beta$-글루코시다제, 엑소글루카나제 및 엔도글루카나제 유전자를 함유한 형질전환체 효모를 배양한 액상섬유소분해효소에 대하 여 인공반추위 배양시험을 통해 완전혼합사료에 대한 적용수준 조사와 더불어 한우 비육 거세우의 사양시험 을 통해 2 종류의 액상섬유소분해효소를 완전혼합사료 에 $1.0 \%$ 수준으로 첨가 급여하여 가축의 성장, 영양소 소화율에 미치는 영향을 알아보고자 실시하였다.

“본 논문은 2007년 농촌진흥청 국책기술개발과제(섬유소분해미생물을 이용한 효소생산 및 산업화기술개발, 과제번호 20070401030006)의 지원으로 수행되었음"

Corresponding author : K. Kook, Division of Animal Science, Chonnam National University Tel: 062-530-2015, Fax:062-530-5084, E-mail: hanwoo@chonnam.ac.kr 


\section{ㅍ. 재료 및 방법}

\section{1. 인공반추위 배양시험}

\section{(1) 시험설계}

인공반추위 배양시험에서 완전혼합사료에 대한 액 상 섬유소분해효소를 0 (대조구), 0.5 및 $1.0 \%$ 수준으 로 3 반복으로 $3,6,12$ 및 24시간 동안 배양하여 $\mathrm{pH}$, 휘발성지방산, 암모니아 농도 및 건물소화율에 미치는 영향을 알아보고자 하였다.

\section{(2) 제 1 위액 및 인공타액의 준비}

인공반추위 배양시험에 사용한 제 1 위액은 광주광역 시 북구 양산동에 위치한 삼호축산 도축장에서 한우 의 반추위로부터 채취하여 4겹의 cheese cloth로 거른 후 $408 \mathrm{xg}$ 에서 10 분간 원심분리하여 사료입자와 proto$\mathrm{zoa}$ 를 제거한 상층액을 사용하였다. 인공타액은 McDougall's buffer solution(Table 1)에 따라 제조하였 으며, 배양시험에 사용하기 전에 $39^{\circ} \mathrm{C}$ 항온수조에서 $\mathrm{O}_{2}$ 를 완전히 제거된 $\mathrm{CO}_{2}$ gas를 주입하여 혐기적 상태 로 유지시킨 후 사용하였다 (Maeng 등, 1976).

Table 1. Chemical composition of McDougall's buffer solution

\begin{tabular}{|c|c|}
\hline Items & Contents (g) \\
\hline $\mathrm{NaHCO}_{3}$ & 9.80 \\
\hline $\mathrm{Na}_{2} \mathrm{HPO}_{4} \cdot 7 \mathrm{H}_{2} \mathrm{O}$ & 7.00 \\
\hline $\mathrm{KCl}$ & 0.57 \\
\hline $\mathrm{NaCl}$ & 0.47 \\
\hline $\mathrm{CaCl}_{2}{ }^{\text {a) }}$ & 0.04 \\
\hline $\mathrm{MgSO}_{4} \cdot 7 \mathrm{H}_{2} \mathrm{O}$ & 0.12 \\
\hline Deionized water(m $\ell)$ & 1,000 \\
\hline Final $\mathrm{pH}$ & $6.8 \sim 6.9$ \\
\hline
\end{tabular}

${ }^{\text {a) }} \mathrm{CaCl}_{2}$ are added just prior to use.

(3) 배양기질의 준비

배양에 사용된 완전혼합사료의 배합원료 및 화학적 조성은 Table 3에 나타내었으며, 이를 배양을 위해 60 ${ }^{\circ} \mathrm{C}$ drying oven에 48 시간 건조 후, $1 \mathrm{~mm}$ screen이 장착 된 Wiley mill로 분쇄하여 미세입자는 제거하여 배양 기질로 사용하였다.

\section{(4) 시험진행방법}

Nylon bag (Nytex, B and SH Thompson, Ltd., $6 \times 12 \mathrm{~cm}$, pore size $50 \mu \mathrm{m}$ )에 배양기질로 완전혼합사료 5 $\mathrm{g}$ 과 액상 Fibrolytic Enzyme Products (FEP)를 각각 0.5 및 $1.0 \%$ 수준으로 첨가한 후 배양동안 $\mathrm{bag}$ 이 뜨지 않 도록 유리구슬을 넣어 fishing line으로 묶은 후 $250 \mathrm{ml}$
의 Culture bottle에 넣었다. $39^{\circ} \mathrm{C}$ 로 보온 및 혐기적 상 태로 유지된 제 1 위액 $100 \mathrm{ml}$ 와 인공타액 $100 \mathrm{ml}$ 을 넣 은 다음 $\mathrm{O}_{2}$ 가 제거된 $\mathrm{CO}_{2}$ gas를 5 분간 주입하여 혐기 적 상태를 유지시켰다. $50 \mathrm{cc}$ 주사기가 장착된 고무마 개로 단단히 마개한 후 $39^{\circ} \mathrm{C}$ 의 진탕배양기에서 분당 110 회 속도로 shaking시켜 배양하였다.

(5) 분석방법

1) $\mathbf{p H}$

배양시간에 따라 배양액을 $10 \mathrm{ml}$ 씩 채취하여 즉시 $\mathrm{pH}$ meter (Toledo 340, UK)를 이용하여 측정한 후 배 양액을 원심분리 $\left(17,000 \mathrm{xg}, 4^{\circ} \mathrm{C}, 15\right.$ 분간)하여 상층액을 취해서 분석시까지 냉동보관 $\left(-80^{\circ} \mathrm{C}\right)$ 하였다.

\section{2) 휘발성지방산}

휘발성지방산은 Erwin 등(1961)의 방법에 따라 상층 액 $1 \mathrm{ml}$ 에 $25 \%$ metaphosphoric acid $100 \mu l$ 를 첨가하고, $3,000 \mathrm{rpm}$ 에서 15 분간 원심분리한 후 상층액을 gas chromatography (Varian 3400 USA)에 주입하여 분석하 였다. 휘발성지방산 분석에 사용된 column은 $30-\mathrm{m}$ capillary column (Supelcowax 10, $0.53 \mathrm{~mm} \mathrm{ID,} 1.0 \mu \mathrm{m}$ film thickness, Supelco. Co.)이었으며, decter는 FID (flame ionization decter)이었다. Gas chromatography의 분석조건은 injector와 decter 온도가 각각 $170^{\circ} \mathrm{C}$ 와 190 ${ }^{\circ} \mathrm{C}$ 이었으며, column 온도는 초기온도 $120^{\circ} \mathrm{C}$ 에서 시작 하여 매분당 $10^{\circ} \mathrm{C}$ 씩 승온하여 $170^{\circ} \mathrm{C}$ 까지 도달시켰다. Carrier gas로서 N2를 사용하여 flow rate는 분당 $30 \mathrm{ml}$ 가 되도록 하였고 split ratio는 20:1로 하였다.

\section{3) 암모니아 농도}

암모니아 농도는 Chaney와 Marbach(1962) 방법에 의 하여 파장 $630 \mathrm{~nm}$ 에서 측정하였다.

\section{4) 건물소화율}

In vitro 건물소화율은 12 시간과 24 시간 배양을 종료 한 후 nylon bag를 꺼내어 흐르는 수돗물에 의해 bag 에 붙어있는 rumen ingesta를 맑아질 때까지 세척하여 제거시켰다. 그리고 nylon bag을 탈수하여 $65^{\circ} \mathrm{C}$ 의 열 풍순환건조기에서 48 시간 동안 건조한 후 건물소화율 을 측정하였다.

\section{2. 한우 육성우에 대한 사양시험}

\section{(1) 공시동물}

공시동물은 평균체중 $310 \mathrm{~kg}$ 인 비육중 한우 거세우 45 두를 공시하였다.

(2) 시험장소 및 기간

시험장소는 함평축협 생축장에서 2007년 7월부터 2007년 11월까지 4개월 동안 사육 및 사양시험을 수 행하였다.

(3) 시험설계 
시험구는 대조구, FEP-1구 및 FEP-2구의 3개 처리 구로 설계하였으며, 시험구 배치는 3 처리 $\times 5$ 두 $\times 3$ 반 복으로 45 두를 완전임의 배치하였다.

\section{(4) 섬유소분해효소의 준비 및 급여}

섬유소분해효소는 목재부후균 유래 $\beta$-글루코시다제, 엑소글루카나제 및 엔도글루카나제 유전자를 함유한 형질전환체 효모를 배양한 액상섬유소분해효소로 0.5 $\%$ 및 $1.0 \%$ 첨가수준으로 완전혼합사료에 첨가하여 급여하였다.

\section{(5) 시험사료 및 사양관리}

시험사료는 완전혼합사료에 급여하였으며, 시험사료 의 일반성분은 $\mathrm{AOAC}$ (1996) 방법으로 분석하였으며, 그 화학적 성분은 Table 2와 같다. 시험축은 개방식 우사에서 사양했으며, 사양시험 동안 미네랄블록 및 물은 자유채식토록 하였다.

\section{(6) 조사항목 및 조사방법}

\section{1) 체중 및 사료섭취량 조사}

체중은 시험개시기와 종료기에 걸쳐 2회 측정하였 으며, 사료섭취량은 매일 아침사료를 급여하기 전 전

Table 2. Ingredients and chemical compositions of total mixed ration used in experiment

\begin{tabular}{lc}
\hline Items & Total mixed ration \\
\hline \hline Ingredient composition & $\ldots$ \% \\
Corn, ground & 2.0 \\
Lupin F & 2.0 \\
Whole cottonseed & 3.0 \\
Wheat bran & 2.0 \\
Corn products & 24.0 \\
Rice bran & 2.0 \\
Beetpulp & 4.0 \\
OEM pellet & 3.0 \\
Soybean meal & 1.0 \\
Molasses & 2.0 \\
Products & 1.0 \\
Products water & 29.0 \\
Limestone & 0.7 \\
Dawumin & 0.3 \\
grass & 15.5 \\
Blue grass & 7.5 \\
Pineapple pulp & 1.0 \\
Chemical composition & \\
Dry matter & 92.9 \\
CP & 19.0 \\
NDF & 29.3 \\
ADF & 16.1 \\
Ether extract & \\
\hline
\end{tabular}

일에 급여한 사료의 잔량을 측정하는 방법으로 조사 하였다.

2) 영양소 소화율 조사

각 영양소의 소화율을 구하기 위하여 시험기간중 2 일간 분을 채취하고 이 채취한 분을 $60^{\circ} \mathrm{C}$ drying oven 에서 3 일간 건조한 후 wiley mill로 분쇄하여 일반분 석 시료로 사용하였다. 영양소 소화율은 섭취한 사료 건물량에서 채취한 분 건물량을 뺀 값으로 소화된 양 으로 하여 섭취량에 대한 비율로 나타냈다.

\section{(7) 통계처리}

본 시험에서 얻어진 자료의 통계처리는 SAS pro$\operatorname{gram}(2000)$ 을 분산분석과 t-test를 실시하여 상호간의 통계적인 차이를 분석하였다.

\section{III. 결과 및 고찰}

\section{1. 인공반추위 배양시험}

(1) $\mathrm{pH}$

완전혼합사료에 액상 섬유소분해효소 적용수준이 반추위 $\mathrm{pH}$ 에 미치는 영향은 Table 3 에 나타내었다. $\mathrm{pH}$ 는 배양 3 시간 및 6시간에는 액상 섬유소분해효소 에 의한 차이는 나타나지 않았지만 배양 9시간 이후 에는 액상 섬유소분해효소 $1.0 \%$ 첨가구에서 비교적 높게 나타났다. 이러한 $\mathrm{pH}$ 의 증가는 반추위미생물 및 액상 섬유소분해효소에 의해 반추위내 섬유소분해 증 가에 의한 것으로 사료된다(Beauchemin 등, 2001).

Table 3. Effect of aqueous FEP supplementation levels on in vitro ruminal $\mathrm{pH}$

\begin{tabular}{cccc}
\hline $\begin{array}{c}\text { Incubation } \\
\text { time(hr) }\end{array}$ & Control & $0.5 \%$ & $1.0 \%$ \\
\hline \hline 3 & $6.32 \pm 0.07$ & $6.34 \pm 0.04$ & $6.37 \pm 0.04$ \\
6 & $6.34 \pm 0.04$ & $6.28 \pm 0.03$ & $6.33 \pm 0.08$ \\
9 & $6.24 \pm 0.03$ & $6.25 \pm 0.07$ & $6.28 \pm 0.10$ \\
12 & $6.12 \pm 0.10$ & $6.20 \pm 0.05$ & $6.25 \pm 0.07$ \\
24 & $6.02 \pm 0.04$ & $6.15 \pm 0.07$ & $6.17 \pm 0.05$ \\
\hline
\end{tabular}

Values mean \pm SE.

(2) 휘발성지방산 조성

완전혼합사료에 액상 섬유소분해효소 적용수준이 반추위 휘발성지방산에 미치는 영향은 Table 4에 나타 내었다. Acetate는 배양 3,6 및 9시간에는 액상 섬유 소분해효소 첨가에 의해 약간 증가하는 경향이었다. 배양 12 시간에는 액상 섬유소분해효소 $0.5 \%$ 및 $1.0 \%$ 첨가구가 대조구에 비해 각각 13.4 및 $15.6 \%$ 증가하였 으며 $(\mathrm{p}<0.05)$, 배양 24 시간에는 6.7 및 $20.9 \%$ 증가하였 다 $(\mathrm{p}<0.05)$. 특히 이러한 경향은 액상 섬유소분해효소 
Table 4. Effect of aqueous FEP supplementation levels on in vitro volatile fatty acids concentrations

\begin{tabular}{|c|c|c|c|}
\hline $\begin{array}{c}\text { Incubation } \\
\text { time(hr) }\end{array}$ & Control & $0.5 \%$ & $1.0 \%$ \\
\hline \multicolumn{4}{|c|}{ 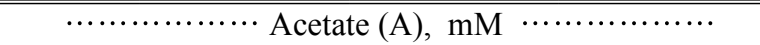 } \\
\hline 3 & $39.15 \pm 1.97$ & $40.25 \pm 1.99$ & $41.26 \pm 2.01$ \\
\hline 6 & $45.87 \pm 2.65$ & $46.78 \pm 2.75$ & $49.85 \pm 2.88$ \\
\hline 9 & $54.28 \pm 3.15$ & $57.38 \pm 3.24$ & $59.63 \pm 3.33$ \\
\hline 12 & $57.78 \pm 4.65^{b}$ & $64.35 \pm 6.01^{\mathrm{ab}}$ & $66.78 \pm 3.22^{\mathrm{a}}$ \\
\hline 24 & $68.37 \pm 5.37^{b}$ & $72.95 \pm 5.02^{\mathrm{ab}}$ & $82.65 \pm 6.44^{\mathrm{a}}$ \\
\hline \multicolumn{4}{|c|}{$\ldots \ldots \ldots \ldots \cdots$ Propionate $(\mathrm{P}), \mathrm{mM} \cdots$} \\
\hline 3 & $14.75 \pm 0.12$ & $16.68 \pm 0.14$ & $17.21 \pm 0.19$ \\
\hline 6 & $20.46 \pm 0.98$ & $18.60 \pm 0.87$ & $19.35 \pm 0.95$ \\
\hline 9 & $22.98 \pm 1.08$ & $22.34 \pm 1.06$ & $24.56 \pm 1.13$ \\
\hline 12 & $23.54 \pm 1.14$ & $24.65 \pm 1.27$ & $24.56 \pm 1.11$ \\
\hline 24 & $26.75 \pm 1.45$ & $28.72 \pm 1.49$ & $31.25 \pm 1.52$ \\
\hline \multicolumn{4}{|c|}{$\cdots \cdots \cdots \cdots$ Butyrate, $\mathrm{mM} \cdots \cdots \cdots \cdots \cdots \cdots$} \\
\hline 3 & $8.23 \pm 0.07$ & $8.94 \pm 0.08$ & $9.14 \pm 0.11$ \\
\hline 6 & $12.34 \pm 0.14$ & $10.87 \pm 0.11$ & $13.24 \pm 0.17$ \\
\hline 9 & $14.65 \pm 0.64$ & $12.54 \pm 0.49$ & $14.27 \pm 0.52$ \\
\hline 12 & $13.98 \pm 0.46$ & $15.89 \pm 0.73$ & $15.08 \pm 0.69$ \\
\hline 24 & $17.26 \pm 0.76$ & $18.35 \pm 0.84$ & $18.63 \pm 0.87$ \\
\hline \multicolumn{4}{|c|}{ Valerate, $\mathrm{mM}$ …............ } \\
\hline 3 & $1.78 \pm 0.02$ & $2.04 \pm 0.03$ & $2.04 \pm 0.03$ \\
\hline 6 & & $2.16 \pm 0.02$ & \pm 0.02 \\
\hline 9 & $2.45 \pm 0.04$ & $2.37 \pm 0.02$ & $2.42 \pm 0.03$ \\
\hline 12 & $2.48 \pm 0.03$ & $3.64 \pm 0.04$ & $2.67 \pm 0.03$ \\
\hline 24 & $3.27 \pm 0.3$ & $4.30 \pm 0.03$ & $4.82 \pm 0.04$ \\
\hline \multicolumn{4}{|c|}{$\cdots \cdots \cdots$ Iso-butyrate, $\mathrm{mM}$ …............ } \\
\hline 3 & $1.34 \pm 0.01$ & $1.42 \pm 0.01$ & $1.45 \pm 0.01$ \\
\hline 6 & $1.52 \pm 0.01$ & $1.52 \pm 0.02$ & $1.50 \pm 0.01$ \\
\hline 9 & $2.04 \pm 0.01$ & $1.75 \pm 0.01$ & $1.72 \pm 0.00$ \\
\hline 12 & $1.64 \pm 0.02$ & $2.03 \pm 0.03$ & $1.88 \pm 0.02$ \\
\hline 24 & $2.30 \pm 0.02$ & $2.45 \pm 0.03$ & $2.67 \pm 0.03$ \\
\hline \multicolumn{4}{|c|}{$\cdots \ldots \ldots$ Iso-valerate, $\mathrm{mM} \cdots \ldots \ldots \ldots \ldots$} \\
\hline 3 & $2.36 \pm 0.02$ & $2.51 \pm 0.02$ & $2.52 \pm 0.02$ \\
\hline 6 & $2.47 \pm 0.03$ & $2.41 \pm 0.02$ & $2.34 \pm 0.02$ \\
\hline 9 & $3.24 \pm 0.02$ & $3.08 \pm 0.03$ & $3.01 \pm 0.02$ \\
\hline 12 & $2.98 \pm 0.01$ & $3.56 \pm 0.02$ & $3.24 \pm 0.02$ \\
\hline 24 & $4.35 \pm 0.04$ & $4.98 \pm 0.04$ & $5.24 \pm 0.05$ \\
\hline \multicolumn{4}{|c|}{ al VFAs, mM …........... } \\
\hline 3 & $67.61 \pm 4.79$ & $71.84 \pm 5.16$ & $73.62 \pm 5.28$ \\
\hline 6 & $84.69 \pm 7.35$ & $82.34 \pm 7.48$ & $88.34 \pm 7.86$ \\
\hline 9 & $99.64 \pm 10.02$ & $99.46 \pm 10.11$ & $105.61 \pm 11.79$ \\
\hline 12 & $102.40 \pm 12.30^{\mathrm{b}}$ & $114.12 \pm 13.20^{\mathrm{a}}$ & $114.21 \pm 14.37^{\mathrm{a}}$ \\
\hline 24 & $122.30 \pm 14.04^{\mathrm{b}}$ & $131.75 \pm 14.20^{\mathrm{a}}$ & $145.26 \pm 13.20^{\mathrm{a}}$ \\
\hline \multicolumn{4}{|c|}{ 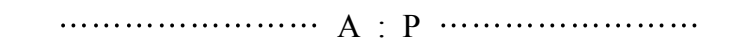 } \\
\hline 3 & $2.65 \pm 0.04$ & $2.41 \pm 0.05$ & $2.40 \pm 0.02$ \\
\hline 6 & $2.24 \pm 0.02$ & $2.52 \pm 0.02$ & $2.58 \pm 0.03$ \\
\hline 9 & $2.36 \pm 0.01$ & $2.57 \pm 0.03$ & $2.43 \pm 0.02$ \\
\hline 12 & $2.45 \pm 0.01$ & $2.61 \pm 0.02$ & $2.72 \pm 0.03$ \\
\hline 24 & $2.56 \pm 0.02$ & $2.54 \pm 0.03$ & $2.64 \pm 0.03$ \\
\hline
\end{tabular}

Values mean \pm SE.

${ }^{\mathrm{a}, \mathrm{b}}$ Values with different superscripts in the same row differ at $\mathrm{p}<0.05$.
$1.0 \%$ 첨가구에서 비교적 높게 나타났다. Propionate 및 butyrate 등의 휘발성지방산은 액상 섬유소분해효소 첨 가에 의해 약간 증가하는 경향이었으며 배양시간이 경과함에 따라 증가폭이 크게 나타났으나 유의적인 차이는 나타나지 않았다. 총휘발성지방산 농도는 배양 12 시간에 대조구, $0.5 \%$ 및 $1.0 \%$ 에서 각각 102.40 , 114.12 및 $114.21 \mathrm{mM}$ 로 액상 섬유소분해효소 첨가에 의해 대조구보다 각각 $11.5 \%$ 씩 증가함을 나타내었다 $(\mathrm{p}<0.05)$. 배양 24 시간에는 대조구, $0.5 \%$ 및 $1.0 \%$ 에서 각각 $122.30,131.75$ 및 $145.26 \mathrm{mM}$ 로 액상 섬유소분해 효소 첨가에 의해 대조구보다 7.7 및 $18.8 \%$ 증가함을 나타내었다 $(\mathrm{p}<0.05) . \mathrm{A} / \mathrm{P}$ 비율에 있어서도 FEP 첨가에 의해 증가시키는 것으로 나타났다. 이러한 결과는 Feng 등 (1996)이 exogenous enzyme이 반추위내 발효에 유의한 영향을 미치지 않는다는 보고와는 상이한 결 과였다.

\section{(3) 암모니아}

완전혼합사료에 액상 섬유소분해효소 적용수준이 반추위 $\mathrm{pH}$ 에 미치는 영향은 Table 5에 나타내었다. 배 양 3 시간에는 액상 섬유소분해효소 $1.0 \%$ 에서 약간 증 가하였으나 배양 6시간 이후에는 처리구간에 차이가 없었다. 이러한 섬유소분해효소 첨가에 의한 반추위내 암모니아 질소 농도가 증가한 경향은 효소에 의한 사 료내 단백질분해가 증가에 기인된 것으로 사료된다 (Hristov 등, 1998, 2000).

Table 5. Effect of aqueous FEP supplementation levels on in vitro ammonia- $\mathrm{N}$ concentration $(\mathrm{mg} / \mathrm{mL})$

\begin{tabular}{cccc}
\hline $\begin{array}{c}\text { Incubation } \\
\text { time(hr) }\end{array}$ & Control & $0.5 \%$ & $1.0 \%$ \\
\hline \hline 3 & $5.36 \pm 3.21$ & $5.41 \pm 2.72$ & $6.04 \pm 3.07$ \\
6 & $19.63 \pm 3.62$ & $18.55 \pm 2.50$ & $19.25 \pm 2.82$ \\
9 & $30.74 \pm 5.01$ & $28.91 \pm 4.35$ & $24.58 \pm 3.24$ \\
12 & $45.62 \pm 4.56$ & $46.88 \pm 3.68$ & $45.78 \pm 3.50$ \\
24 & $47.24 \pm 5.66$ & $48.27 \pm 4.50$ & $49.25 \pm 3.54$ \\
\hline
\end{tabular}

Values mean \pm SE.

(4) 건물소화율

완전혼합사료에 액상 섬유소분해효소 적용수준이 반추위내 건물소화율에 미치는 영향은 Table 6에 나타 내었다. 반추위내 건물소화율은 배양 12 시간에는 FEP $0.5 \%$ 및 $1.0 \%$ 구에서 다소 증가하였으나 유의적인 차 이는 나타나지 않았지만 배양 24시간에는 대조구, $\mathrm{FEP}-1$ 및 $\mathrm{FEP}-2$ 에서 각각 46.5, 52.6 및 54.8\%로 액상 섬유소분해효소 첨가에 의해 대조구보다 13.1 및 $17.9 \%$ 증가하였다 $(\mathrm{p}<0.05)$. 일반적으로 exogenous enzyme의 반추동물사료내 첨가는 반추위내 미생물이 이용 가능한 환원당의 농도를 증가시키고 그 결과 사 
Table 6. Effect of aqueous FEP supplementation levels on in vitro dry matter disappearance (\%)

\begin{tabular}{cccc}
\hline $\begin{array}{c}\text { Incubation } \\
\text { time(hr) }\end{array}$ & Control & $0.5 \%$ & $1.0 \%$ \\
\hline \hline 12 & $25.1 \pm 4.26$ & $28.3 \pm 3.87$ & $31.0 \pm 6.06$ \\
24 & $46.5 \pm 3.78^{\mathrm{b}}$ & $52.6 \pm 5.23^{\mathrm{a}}$ & $54.8 \pm 5.83^{\mathrm{a}}$ \\
\hline
\end{tabular}

Values mean \pm SE.

${ }^{a, b}$ Values with different superscripts in the same row differ at $\mathrm{p}<0.05$.

료내 반추위분해단백질과 발효동조화현상이 나타나 미생물단백질합성량이 증가하며 아울러 반추위 미생 물에 의한 소화율이 증가하는 것으로 보고되고 있다 (Hristov 등, 1998; Rode 등, 1999; Wang 등, 2001).

\section{2. 한우 거세우 사양시험}

\section{(1) 사양성적}

액상 섬유소분해효소를 한우 거세 비육우의 완전혼 합사료에 첨가-급여에 따른 체중, 사료섭취량에 미치 는 영향은 Table 7에 나타내었다. 일당증체량은 대조 구, FEP-1 및 FEP-2에서 각각 $0.81,0.95$ 및 $0.91 \mathrm{~kg} / \mathrm{d}$ 로 액상 섬유소분해효소 첨가에 의해 대조구보다 $17.7 \%$ 및 $12.4 \%$ 증가하였으나 유의적인 차이는 나타 나지 않았다 $(\mathrm{p}>0.05)$. 사료섭취량은 액상 섬유소분해 효소 첨가에 의해 영향을 받지 않은 것으로 나타났다. 사료효율은 대조구, FEP-1 및 FEP-2에서 각각 12.84, 10.63 및 11.53으로 대조구에 비해 액상 섬유소분해효 소 첨가구에서 개선되는 경향이었다 $(\mathrm{p}>0.05)$. 이러한 결과는 Beauchemin 등 (1997)과 McAllister 등 (1999)이 비육우에 섬유소분해효소를 급여시 증체량이 증가하

Table 7. Effect of Fibrolytic Enzymes Product (FEP) on growth performance of Hanwoo steers

\begin{tabular}{lccc}
\hline Items & Control & FEP-1 & FEP-2 \\
\hline \hline $\begin{array}{l}\text { Initial weight } \\
(\mathrm{kg})\end{array}$ & $313.8 \pm 25.3$ & $309.7 \pm 30.1$ & $311.5 \pm 29.0$ \\
\hline $\begin{array}{l}\text { Final weight } \\
(\mathrm{kg})\end{array}$ & $412.0 \pm 23.9$ & $423.5 \pm 27.3$ & $420.8 \pm 20.5$ \\
\hline $\begin{array}{l}\text { Daily weight gain } \\
(\mathrm{kg} / \mathrm{d})\end{array}$ & $0.81 \pm 0.02$ & $0.95 \pm 0.05$ & $0.91 \pm 0.02$ \\
\hline $\begin{array}{l}\text { Feed intake } \\
(\mathrm{kg} / \mathrm{d})\end{array}$ & $10.4 \pm 3.20$ & $10.1 \pm 3.24$ & $10.5 \pm 2.78$ \\
\hline $\begin{array}{l}\text { Feed/gain } \\
(\mathrm{kg})\end{array}$ & $12.84 \pm 2.89$ & $10.63 \pm 2.09$ & $11.53 \pm 2.12$ \\
\hline $\begin{array}{l}\text { Values mean } \pm \text { SE. } \\
\text { aal }\end{array}$ & & & \\
\hline
\end{tabular}

였다는 보고와 일치하였다.

\section{(2) 영양소 소화율}

액상 섬유소분해효소를 한우 거세 비육우의 완전혼 합사료에 첨가- 급여에 따른 영양소소화율에 미치는 영향은 Table 8에 나타내었다. 건물소화율은 대조구, FEP-1 및 FEP-2에서 각각 62.2, 68.7 및 69.2\%로 액상 섬유소분해효소 첨가에 의해 대조구보다 10.5 및 $11.3 \%$ 증가하였다 $(\mathrm{p}<0.05)$. 조단백질 소화율은 액상 섬유소분해효소 첨가에 의해 증가하였으나 유의적인 차이는 나타나지 않았다. 조지방소화율은 액상 섬유소 분해효소 첨가에 의해 영향을 받지 않은 것으로 나타 났다. 조섬유소화율은 대조구, FEP-1 및 FEP-2에서 각 각 46.4, 54.5 및 $53.9 \%$ 로 액상 섬유소분해효소 첨가 에 의해 대조구보다 17.5 및 $16.2 \%$ 증가하였다(p< 0.05). NDF 소화율은 대조구, FEP-1 및 FEP-2에서 각 각 $58.8,63.5$ 및 $63.6 \%$ 로 액상 섬유소분해효소 첨가 에 의해 대조구보다 8.0 및 $8.2 \%$ 증가하였다 $(\mathrm{p}<0.05)$. $\mathrm{ADF}$ 소화율은 대조구, FEP-1 및 FEP-2에서 각각 55.2, 64.6 및 $67.2 \%$ 로 액상 섬유소분해효소 첨가에 의해 대 조구보다 17.0 및 $21.7 \%$ 증가하였다 $(\mathrm{p}<0.05)$. 비구조탄 수화물 소화율은 액상 섬유소분해효소 첨가에 의해 약간 증가하는 경향을 나타내었다. 이러한 연구결과는 Feng 등 (1996), Lewis 등 (1996) 및 Beauchemin 등 (1997)이 비육우에 섬유소분해효소를 첨가했을때 NDF 소화율과 $\mathrm{ADF}$ 소화율이 증가하였다는 보고와 유사하 였다.

Table 8. Digestibility (\%) of the diets as influenced by supplement of FEP

\begin{tabular}{|c|c|c|c|}
\hline Items & Control & FEP-1 & FEP-2 \\
\hline Dry matter & $62.2 \pm 2.34^{\mathrm{b}}$ & $68.7 \pm 6.42^{\mathrm{a}}$ & $69.2 \pm 2.64^{\mathrm{a}}$ \\
\hline Crude protein & $58.7 \pm 2.64$ & $62.4 \pm 5.14$ & $63.2 \pm 4.30$ \\
\hline Ether extract & $83.2 \pm 3.04$ & $84.7 \pm 2.67$ & $83.1 \pm 2.54$ \\
\hline Crude fiber & $46.4 \pm 2.52^{\mathrm{b}}$ & $54.5 \pm 2.75^{\mathrm{a}}$ & $53.9 \pm 2.33^{\mathrm{a}}$ \\
\hline NDF & $58.8 \pm 2.14^{\mathrm{b}}$ & $63.5 \pm 1.68^{\mathrm{a}}$ & $63.6 \pm 3.04^{\mathrm{a}}$ \\
\hline $\mathrm{ADF}$ & $55.2 \pm 2.68^{\mathrm{b}}$ & $64.6 \pm 4.20^{\mathrm{a}}$ & $67.2 \pm 2.48^{\mathrm{a}}$ \\
\hline $\begin{array}{l}\text { Non-fibrous } \\
\text { carbohydrate }\end{array}$ & $83.7 \pm 21.3$ & $84.7 \pm 18.7$ & $85.9 \pm 20.9$ \\
\hline
\end{tabular}

\section{IV. 요 약}

본 연구는 목재부후균 유래 $\beta$-글루코시다제, 엑소글 루카나제 및 엔도글루카나제 유전자를 함유한 형질전 환체 효모를 배양한 액상섬유소분해효소에 대하여 인 공반추위 배양시험을 통해 완전혼합사료에 대한 적용 수준 조사와 더불어 한우 비육 거세우의 사양시험을 
통해 2 종류의 액상섬유소분해효소를 완전혼합사료에 $1.0 \%$ 수준으로 첨가 급여하여 가축의 성장, 영양소소 화율에 미치는 영향을 알아보고자 실시하였다.

1. 인공반추위 배양시험을 통해 완전혼합사료에 대 한 액상 섬유소분해효소 첨가에 의해 $\mathrm{pH}$ 가 약간 증가 하는 경향이었다. 휘발성지방산에서 acetate 비율이 배 양 12 와 24 시간에 유의적으로 $(\mathrm{p}<0.05)$ 높게 나타났으 며 총휘발성지방산 농도 역시 배양 12 와 24시간에 유 의적으로 $(\mathrm{p}<0.05)$ 증가시켰으며 $1.0 \%$ 첨가구에서 효과 적이었다. 건물소화율은 배양 24 시간에 액상 섬유소분 해효소 첨가구에서 유의적으로 $(\mathrm{p}<0.05)$ 증가하였다.

2. 한우 거세우 사양시험에서는 액상 섬유소분해효 소 급여에 의해 일당증체량과 사료효율이 개선되는 경향이었다. 영양소 소화율에서는 $\mathrm{DM}$, 조섬유, $\mathrm{NDF}$ 및 $\mathrm{ADF}$ 소화율이 액상 섬유소분해효소 첨가에 의해 유의적으로 $(\mathrm{p}<0.05)$ 증가하였다.

따라서 인공반추위 배양시험을 통해 액상 섬유소분 해효소 $1.0 \%$ 첨가가 비교적 반추위발효 양상을 개선 시키었으며, 한우 사양시험에서도 2 종류의 액상 섬유 소분해효소 $1.0 \%$ 급여가 일당증체량 및 사료효율 개 선효과가 있었다.

\section{V. 인 용 문 헌}

1. AOAC. 1996. Official Methods of Analysis. 16then. Association of Official Association of Official Analytical Chemists, Washington, DC.

2. Beauchemin, K. A., Collombatto, D., Morgavi, D. P. and Yang, Y. Z. 2003. Use of exogenous fibrolytic enzymes to improve feed utilization by ruminants. J. Anim. Sci. 81(E. Suppl. 2):E37-E47.

3. Beauchemin, K. A., Morgavi, D. P., McAllister, T. A., Yang, W. Z. and Rode, L. M. 2001. The use of enzymes in ruminant diets : In Recent advances in animal nutrition, pp. 297-322. Edited by P. C. Garnsworthy and D. J. A. Cole. Nottingham. Univ. Press.

4. Beauchemin, K. A., Jones, S. D. M., Rode, L. M. and Sewalt, V. J. H. 1997. Effects of fibrolytic enzymes in corn or barley diets on performance and carcass characteristics of feedlot cattle. Can. J. Anim. Sci. 77:645-653.

5. Chaney, A. L. and Marbach, E. P. 1962. Modified reagents for determination of urea and ammonia. Clin. Biochem. 8:130-132.

6. Feng, P., Hunt, C. W., Pritchard, G. T. and Julien, W. E. 1996. Effect of enzymes preparations on in situ and in vitro degradation and in vivo digestive characteristics of mature cool-season grass forage in beef steers. J. Anim. Sci. 74:1349-1357.

7. Hristov, A. N., McAllister, T. A. and Cheng, K. J. 1998. Effect of dietary or abomasal supplementation of exogenous polysaccharide-degrading enzymes on rumen fermentation and nutrient digestibility. J. Anim. Sci. 76: 3146-3156.

8. Hristov, A. N., McAllister, T. A. and Cheng, K. J. 2000. Intraruminal supplementation with increasing levels of exogenous polysaccharide-degrading enzymes: effects on nutrient digestion in cattle fed a barley grain diet. J. Anim. Sci. 78:477-487.

9. Lewis, G. E., Hunt, C. W., Sanchez, W. K., Treacher, R., Pritchard, G. T. and Feng, P. 1996. Effect of direct-fed fibrolytic enzymes on the digestive characteristics of a forage-based diet fed to beef stters. Journal of Animal Science, 74, 3020-3028.

10. Maeng, W. J., Van Nevel, C. J., Baldwin, R. L. and Morris, J. G. 1976. Rumen microbial growth rates and yields : Effect of amino acids and protein. J. Dairy Sci. 59:68-79.

11. McAllister, T. A., Oosting, S. J., Popp, J. D., Mir. Z., Yanke, L. J., Hristov, A. N., Treacher, R. J. and Cheng, K. J. 1999. Effect of exogenous enzymes on digestibility of barley silage and growth performance of feedlot cattle. Can. J. Anim. Sci. 79:353-360.

12. Phipps, R. H., Sutton, J. D., Bhat, M. K., Hartnell, G. F., Vicini, J. and Hard, D. L. 2000. Effect of cell-wall degrading enzymes and method of application on feed intake and milk production of Holstein-Friesian dairy cows. J. Dairy Sci 83(Suppl. 1):236-237(Abstr.)

13. Rode, L. M., Yang, W. Z. and Beauchemin, K, A. 1999. Fibrolytic enzyme supplements for dairy cows in early lactation. J. Dairy Sci. 82:2121-2126.

14. SAS. 2000. SAS/STAT User's guide(Release 8.1 ed.). Statistics, SAS Inst, Inc., Cary, NC.

15. Sutton, J. D., Phipps, R. H., Beever, D. E., Humphries, D. J., Hartnell, G. F., Vicini, J. L. and Hard, D. L. 2003. Effect of method of application of a fibrolytic enzyme product on digestive processes and milk production of digestive processes and milk production in HolsteinFriesian cows. J. Dairy Sci. 86:546-556.

16. Wang, Y., McAllister, T. A., Rode, L. M., Beauchemin, K. A., Morgavi, D. P., Nsereko, V. L., Iwaasa, A. D. and Yang, W. Z. 2001. Effects of an exogenous enzyme preparation on microbial protein synthesis, enzyme activity and attachment to feed in the rumen simulation technique (Rusitec). Br. J. Nutr. 85: 325-332.

17. Yang, W. Z., Beauchemin, K. A. and Rode, L. M. 1999. Effects of an enzyme feed additive on extent of digestion and milk production of lactating dairy cows. J. Dairy Sci. 82:325-332.

(접수일자 : 2007. 12. 31. / 수정일자 : 2008. 12. 30./ 채택일자 : 2009. 1. 8.) 